\title{
放射性炭素年代測定を用いた海底土砂の長期的移動・堆積履歴の推定

\author{
Investigation on Long-term Offshore Sedimentation and \\ Sediment Transport Using Radiocarbon Dating
}

\author{
伴野雅之 $^{1}$ ・ 清家弘治 ${ }^{2}$ ・ 小松原純子 ${ }^{3}$ ・栗山善昭 ${ }^{4}$ \\ Masayuki BANNO, Koji SEIKE, Junko KOMATSUBARA and Yoshiaki KURIYAMA
}

\begin{abstract}
Sediment deposition and the origins at water depths of 9 to $19 \mathrm{~m}$ at Kashima-nada Sea were investigated by radiocarbon dating the age of shells contained in the seabed core samples. The older-than-normal shells were used as tracers, which was included in sediments dumped into the sea from 1965 to 1977 , to estimate the offshore sedimentation and sediment transport history. The results showed that the influence of the dumped sediments was observed even at a water depth of $19 \mathrm{~m}$, and it was also indicated that the dumped sediments were not moved in relative deepwater points after the deposition and the dumped sediments eroded after the deposition in relative shallow-water points would be transported and be redeposited.
\end{abstract}

\section{1. はじめに}

水深の深い沖域における海底土砂の移動・堆積過程は 数十年から数百年の非常にゆっくりとした時間スケール で進行し，通常，防災上や海岸管理上の観点からは，そ の影響はほとんど無視できるように思われる。しかしな がら, 実際には沖域の地形やその変化は波の屈折や浅水 変形などにも影響を与えることから, 浅海域の地形変化 にも大きな影響を及ぼす。そのため, 現地における沖域 の海底土砂の移動や堆積状況を十分に理解することは非 常に重要であり, 長期的に安定した海浜の形成及び維持 管理計画には必要不可欠なものである。その移動・堆積 過程の理解のためには, 長期間かつ高頻度で高精度な調 査による沖域の地形変化に関する現況把握が必要である が，従来の調査手法においては，予算や調査期間といっ た制約により，必ずしも十分にその状況や特性を把握す ることは難しいのが現状であった。

他方で，沖域の海底地形は人為的な影響によって大き く変化することがある. 例えば, 港湾の建設や航路の維 持浚渫によって生じた土砂は, しばしば処分もしくは海 岸侵食対策（養浜）を目的として海洋に投入されるが, 大量の土砂が海洋に投入された場合には, 周辺領域内の 総土砂量が大きく増加し, 付近の海岸では堆積が生じや すくなることが知られている（例えば，佐藤ら，1974）. しかしながら，そのように海洋に投入された土砂がどの 程度の時間スケールでどの程度の水深や範囲にまで移

\begin{tabular}{lll}
\hline 1 正会員 & 修(工) & $\begin{array}{l}\text { (独法)港湾空港技術研究所 沿岸環境研 } \\
\text { 究領域沿岸土砂管理研究チーム 研究官 }\end{array}$ \\
2 & 博(理) & 東京大学大気海洋研究所 助教 \\
3 & 博(理) & (独法)産業技術総合研究所 地質情報研 \\
& 究部門平野地質研究グループ 研究員 \\
正会員 & 博 (工) & (独法)港湾空港技術研究所 特別研究官
\end{tabular}

動・堆積し, 地形変化に影響を及ぼすのかといった海洋 投入土砂の移動・堆積特性もまた同様に十分に明らかに されていない.

そこで本研究では，放射性炭素年代測定法により海底 土砂に混在する貝殼の年代を測定することで，数十年ス ケールの土砂の移動・堆積履歴の推定を試みた。具体的 には, 過去に陸域の掘削土砂が海洋投入された鹿島灘に おいて複数の水深帯で採取された海底土砂試料を対象と し, 各水深帯における海洋投入土砂の堆積状況を評価し, 海底土砂の移動・堆積履歴を推定した. 本研究は, これ により沖域における土砂の移動 ・堆積過程の理解を目指 すものである.

\section{2. 評価・検討手法}

\section{（1）放射性炭素年代測定法}

本研究における貝殼の年代測定には放射性炭素年代測 定法を用いた，放射性炭素である ${ }^{14} \mathrm{C}$ は大気中にほぼ一 定の割合で存在し, 光合成などにより固定された後, 環 境中を循環するが, 生物が死亡後は新たな ${ }^{14} \mathrm{C}$ は取り込 まれず，時間とともに一定の割合で減少していく（図-1).

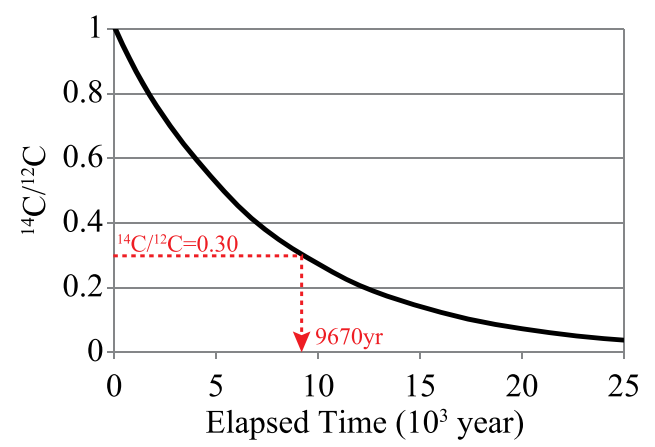

図-1 放射性炭素同位体比の経時的減少を利用した年代の推定 
本手法は, この性質を利用し, ${ }^{14} \mathrm{C}$ の存在率からその有機 物が死亡してからの時間を求めるものであり, 堆積学や 考古学の分野において古環境の復元等に用いられている 手法である（例えば，小松原・木村，2011）。 ${ }^{14} \mathrm{C}$ は半減 期が 5,730 年であり，本手法により炭素を含む物質の年 代を約 60,000 年前まで測定することが可能である。ただ し，海洋の炭素を取り込んで形成された貝殼は通常，海 洋リザーバー効果と呼ばれる年代の遅れが生じることが 知られている（例えば，Shishikura et al., 2007)。これは 貝殸が陸域の生物と比較して海洋を循環した古い炭素を 利用することにより生じるものであり，測定值は大気中 の炭素を直接取り达んだ有機物と比較して数十年から数 百年程度古い年代となる。

なお, 本研究においては, 加速器質量分析法 (AMS 法) により ${ }^{14} \mathrm{C}$ の個数を計数し, ${ }^{14} \mathrm{C}$ 濃度 $\left({ }^{14} \mathrm{C} /{ }^{12} \mathrm{C}\right)$ を測定し た。また，同位体効果の補正のために ${ }^{13} \mathrm{C}$ 濃度 $\left({ }^{13} \mathrm{C} /{ }^{12} \mathrm{C}\right)$ を測定した。放射性炭素年代（Libby Age, yrBP）は半減 期にLibbyの半減期である 5,568年を用い，1950年を基準 として算出した（Stuiver and Polach，1977）.

\section{（2）鹿島港建設に伴う土砂の海洋投入}

茨城県に位置する鹿島港は 1961 年に陸域を掘削して建 設される掘込港湾として建設が開始された。その建設工 事に伴って約 8,600万 $\mathrm{m}^{3}$ の土砂が発生した。 その内, 約 5,000 万 $\mathrm{m}^{3}$ もの大量の土砂が鹿島港南海浜（波崎海岸） の汀線から 500m以内の浅海域に 1965 年から 1977 年にか けて海洋投入された（図-2）。その投入に伴った汀線の前 進によって浜幅が大きく広がった領域の一部（鹿島港南 防波堤近傍）は埋め立てられたものの，その埋立地の土 量を差し引いても海洋投入された土砂量の約半分程度は 海洋に流出したと考えられる.

\section{（3）海洋投入土砂の堆積状況の評価手法}

上述のように鹿島港建設時の海洋投入土砂は陸域を掘 削して発生したものであるため，地層中に含まれる古い 貝殸を多く含有していたものと考えられる。これらの貝 殼は, 通常海底に存在する貝殼と比較して, 年代が非常 に古いと考えられ，本研究ではこれらの古い貝款を海洋 投入土砂の一種のトレーサーとして用い, 海洋投入土砂 の堆積状況を評価することとしたすなわち，一般に貝 殼は偏平形状を有していることから球体形状の砂とは限 界シールズ数などの移動特性は異なるけれども（熊谷ら， 2009), 移動方向や堆積時期などのおおよその傾向は一 致する，そのため, 土砂の投入後, 約 50 年経過した現在 においてトレーサーとした古い年代の貝殸がどの程度の 範囲および堆積層に分布しているかを調查することで海 洋投入土砂の時間的かつ空間的な移動・堆積履歴を追跡 的に推定することができると考えられる.

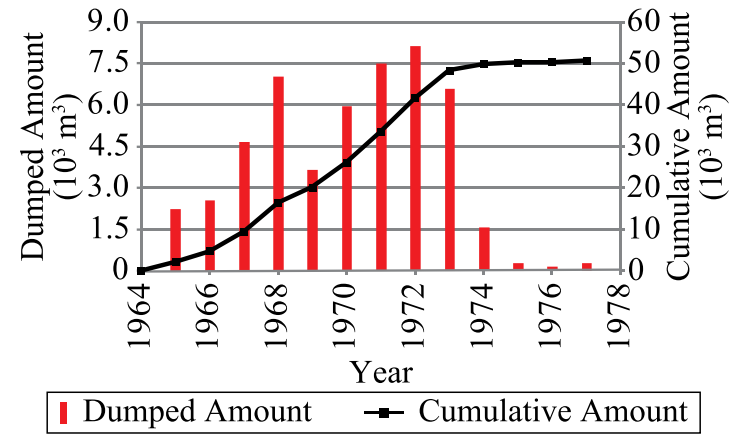

図-2 鹿島港南海浜への土砂の海洋投入量の推移

\section{（4）調查概要}

過去に海洋投入された土砂に含まれていた貝款の年代 を推定するために，図-3に示す鹿島港近辺の陸上におい て鹿島港内の最大水深域よりもやや深い約 $-24 \mathrm{~m}$ までの才 ールコアボーリングを行い, 不擋乱試料を採取した。採 取した陸上ボーリングコア（HORS-1）については，分 画した後, 各層毎に無作為に貝款を採取し，その年代を 測定した.

また，海洋投入土砂由来の古い貝殼の現在の海底にお ける空間的分布状況を評価するために，2010年7月22日， 25日, 26日に扔いて, 図-3に示す茨城県鹿島灘の沖合の 4 地点（水深約 $19 \mathrm{~m}, 15 \mathrm{~m}, 12 \mathrm{~m}, 9 \mathrm{~m}$ ) で約 $1 \mathrm{~m}$ 程度の海 底コア（Core1〜Core4）を採取した。また，図-3には 2010年11月 4 日に実施した測量による採取地点周辺の海 底地形を同時に示す．本研究に打ける高さの基準は波崎 港工事用基準面（T.P. - 0.687m）である。海底コアはポ リカーボネートパイプの打ち込みにより採取され，採取 した海底コアについても同様に各層毎に貝款の年代を測 定した。なお，年代を測定した貝殸の大きさは $1 \mathrm{~cm}$ 程度 のものが最も多かったが, 本研究においてはその形状の 違いによる詳細な検討は行なっていない。また, 参考情 報として海底コア及び陸上ボーリングコアの深さ方向に $5 \mathrm{~cm}$ 間隔で粒度分布を求めた。

\section{3. 海洋投入土砂の性状の推定}

図-4に陸上ボーリングコア内に含まれた貝殼の年代及 び底質の中央粒径の分布を示す。コア内には例外的に約 1.7 万年 3.3 万年前の貝殼が含まれていたけれども，鹿 島港建設により掘削された地層は現在から約 8,000 年前 までに構成されたものであると考えられる。また， $-9 \mathrm{~m}$ $\sim 1 \mathrm{~m}$ の約 5,000 年前 7,500 年前の貝殼の存在は霞ヶ浦の 形成（井内・斎藤，1993）も関係していると考元られ， これらの貝殼の年代值を除くと, 貝殼の年代は深さ方向 にほぼ線形的に古くなっている．このことから，地層の 堆積速度は経時的に大きな変化はなく, ほぼ一定であっ 


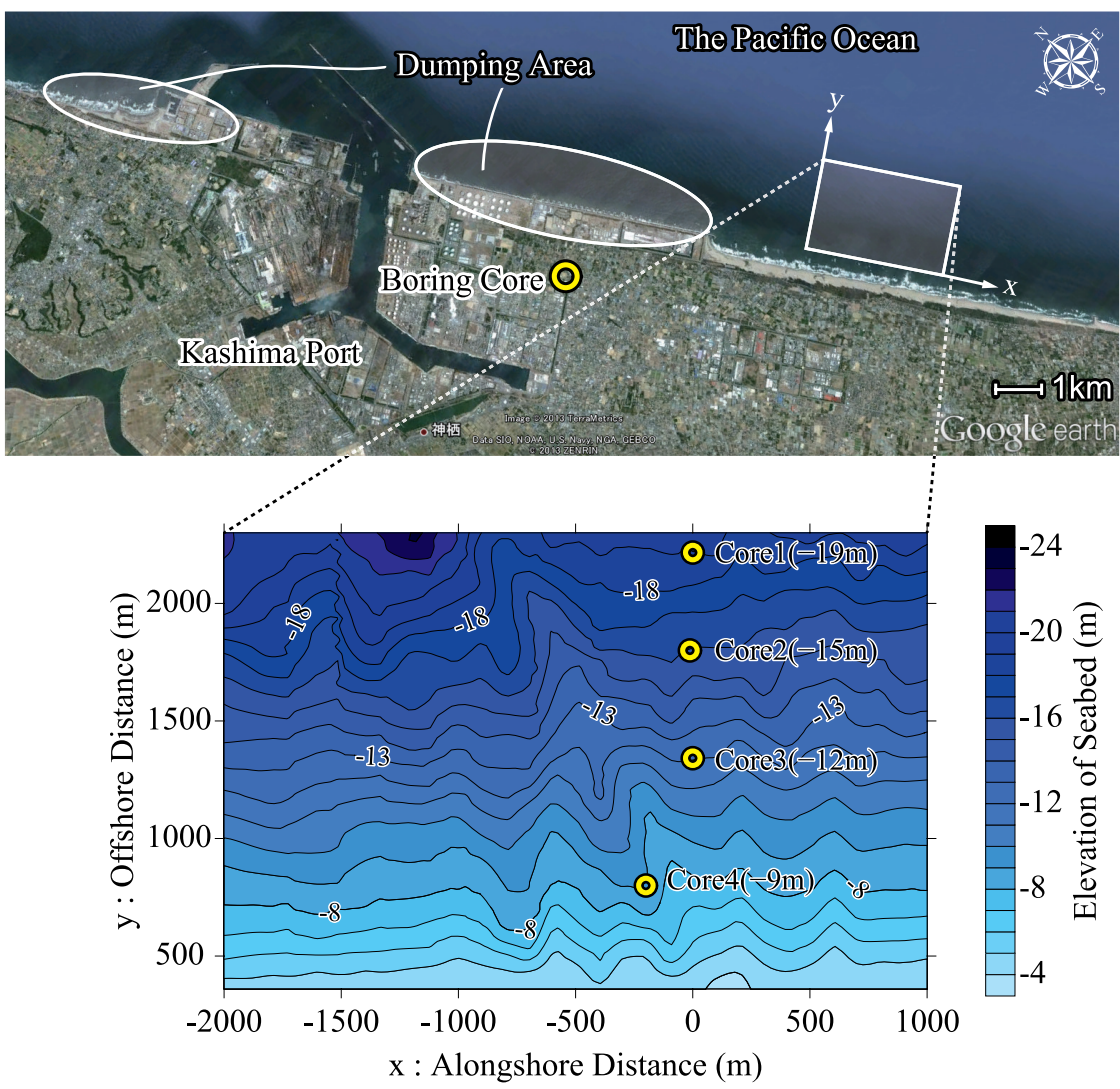

図-3 対象域におけるコア採取位置及びその周辺の海底地形

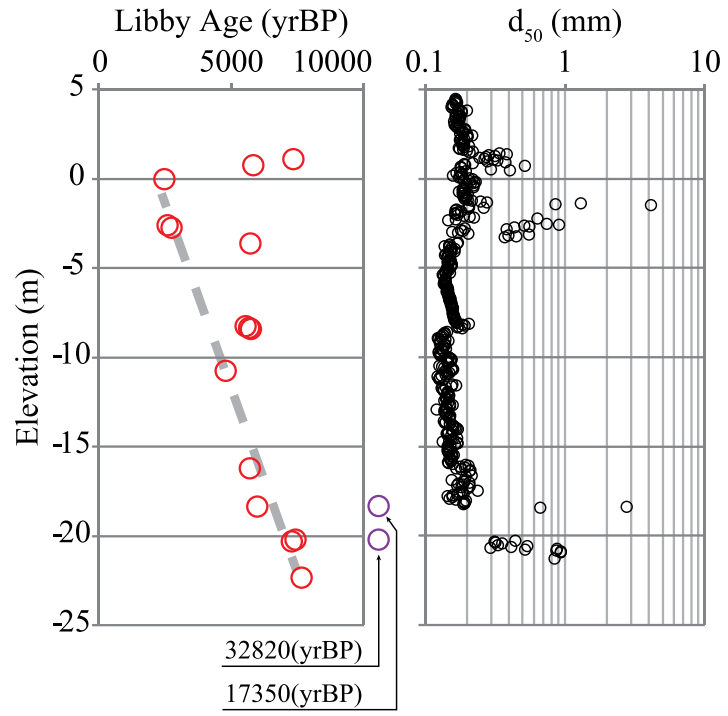

図-4 陸上ボーリングコア (HORS-1) 中の貝殼の年代分布及び 底質の中央粒径（特異的に古い貝殸は紫で枠外に表記.）

たと推測でき，海洋投入土砂には約 2,500 年前〜 8,000 年 前の各年代の貝殼がほぼ均等な量で含まれていたと考え ることができる. 同時に, 陸上ボーリングコア内の最も
新しい貝殼は2,500年前のものであるが，それより新し い貝殼もより海に近い地層には含まれている可能性があ り，海洋投入土砂中にも 2,500 年前よりも新しい貝款は 含まれていたと推測される.

粒径に関しては， $0.2 \mathrm{~mm}$ 以下の粒径がほとんどであり, $0.13 \mathrm{~mm} \sim 0.17 \mathrm{~mm}$ の粒径のものが特に多い.すなわち, 鹿島港建設時に海洋投入された土砂の多くは比較的粒径 の細かい細砂であったと考えられる。一方， $-2 \mathrm{~m} \sim-4 \mathrm{~m}$ 及び $19 \mathrm{~m}$ 以深に粒径の大きい碎などの粗粒分の堆積も見 られた。 なお，図中には示されていないが，-19m以深に おいては非常に大きい亜円礫が存在しており，一部，粒 径の測定はできていない。 また， $-17 \mathrm{~m}$ 以深には粒度分析 の測定限界以下の粘土などの細粒分の堆積層も一部に見 られた。

10,000 年以上前の例外的に古い貝殸が存在していた堆 積層は約 5,000 年 7,000年前の水深 $18 \mathrm{~m} \sim 20 \mathrm{~m}$ であった. この層は上述したように, 非常に粗い礫で構成されてい たことから, 通常の海浜堆積物ではないと考えられ，こ れらの貝殼の存在は, この層が沖積層の基底礫層であっ たことに起因するもの, もしくは河川などで古い堆積層 が侵食され, この時期の堆積物と同時に堆積したこと 


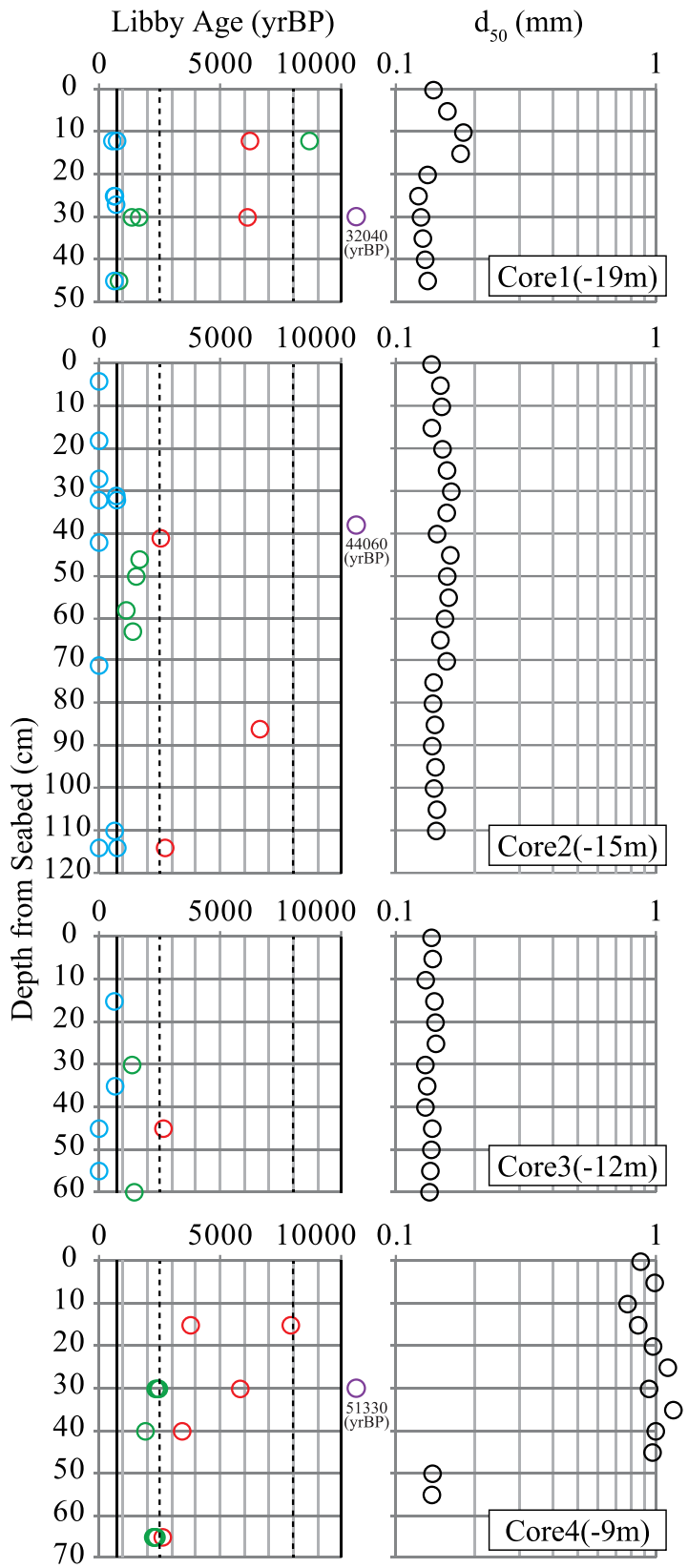

図-5 海底コア中の貝殼の年代分布及び底質の中央粒径 (年 代值による色分けは図-6参照.)

（再堆積）によるものであると考えられる.

\section{4. 土砂の移動・堆積履歴の推定}

\section{（1）海洋投入土砂の堆積状況}

図-5に海底コア内に含まれた貝殸の年代及び底質の中 央粒径を示す．前述のように海洋投入土砂は主に 2,500 年前以降の貝殼で構成され，各年代の貝殸を均等に含ん でいたと考えられる一方で，全海底コア中の貝殸の年代

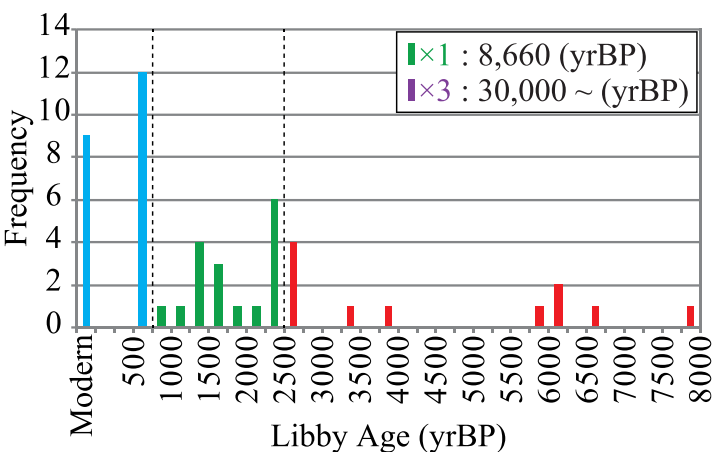

図-6 海底コア中の貝殼の年代頻度分布と分類（測定限界以 上の新しい貝殼はModern と標記. 通常の堆積過程由来 と考えられるものは青, 海洋投入土砂由来と考えられ るものは赤，海洋投入土砂由来の可能性が高いものは 緑，特異的に古い貝殼は紫で表記.)

の頻度分布（図-6）は750年前よりも新しいものが突出 して多い. 貝殼の年代は海洋リザーバー効果により数百 年程度古い年代を示す場合があることを考慮すると， 750 年前よりも新しい貝殼は現在の貝殼として考えるこ とができ，その貝殼を伴った土砂による堆積を通常の堆 積過程，つまり河川からの新たな土砂供給や土砂の海洋 投入以前から海岸に存在していた土砂の沖向き移動によ って生じた堆積として考えることができる。一方，2,500 年前 $~ 8,000$ 年前の貝殼は陸上ボーリングコアに含まれ ていたことから海洋投入土砂由来のものと考えることが でき，その前後である 750 年前〜 2500 年前及び 8,000 年前 $\sim 10,000$ 年前の貝殼は海洋投入土砂由来の可能性が高い ものと考えられる。これに基づき，海底コア中の貝款を 年代毎に図-5及び図-6のように分類し，その貝殼を含む 堆積層の堆積物の由来を推定した。なお，1万年前を超 える特異的に古い貝殼については海洋投入土砂由来の可 能性もあるが，供給源が不明確であることから，分類の 対象から除外した。

この分類に基づくと，Core1においては，海洋投入土 砂由来と考えられる比較的古い貝殼は表層から $12 \mathrm{~cm}$ 及 び $30 \mathrm{~cm}$ に含まれていた。表層から $30 \mathrm{~cm}$ 付近では海洋投 入土砂による堆積が生じたと考えられる一方，表層から $12 \mathrm{~cm}$ の古い貝殼は新しい貝殼と混在した状態にあったこ とから, 表層から $12 \mathrm{~cm}$ 付近の堆積物は海洋投入土砂と 通常の堆積過程による土砂が同時に堆積したものと考え られる. Core2に扔いて, 比較的古い貝殼は表層から約 $40 \mathrm{~cm}$ 以深に存在し，Core3に扔いては，表層から $30 \mathrm{~cm}$ 以 深に存在していた．Core2及びCore3に関しては，いずれ も表層（此較的古い貝殼が存在していた堆積層の上）に 新しい貝款が堆積していることから，海洋投入土砂によ る堆積が生じた後, 通常の堆積過程による土砂の堆積が 生じたものと考えられる．Core4においては，年代測定 
した貝殼からは，通常の堆積過程由来の新しい貝殼が検 出されなかったことから, Core4の堆積物のほとんどは 海洋投入土砂であると考えられる.

\section{（2）海洋投入土砂堆積後の土砂の移動・堆積履歴}

Core2 及びCore3 に関しては，比較的明確に海洋投入土 砂の堆積層と通常の堆積過程による堆積層を分けること ができ, 上述のように海洋投入土砂が堆積した後, 新た に通常の堆積過程による堆積が生じたと考えられた。海 洋投入土砂の堆積後に新たに堆積した量は, Core2に関 しては表層約 $40 \mathrm{~cm}$, Core3に関しては表層約 $30 \mathrm{~cm}$ と考え られる. 通常, 水深が深い領域の方が堆積速度は遅いこ とが多いけれども, 本結果においては水深がより浅い Core3（水深 $12 \mathrm{~m}$ ) の方がCore2（水深 $15 \mathrm{~m}$ ） と比較して 堆積量が少なかった。これは大型の低気圧の通過等に伴 う高波浪による大規模な地形変化（例えば, 武若ら, 2009）によって，水深の浅いCore3がより大きく侵食を 受けたためと考えられる.

\section{（3）粒径の異なる土砂の移動・堆積履歴}

各海底コアに扒いて中央粒径の鉛直分布（図-5）を比 較すると, Core1及びCore4において特徴的な粒径の変化 が見られた。このような鉛直方向の粒径の変化は土砂の 由来や堆積過程が異なることを意味するものである. Core 1 及びCore 4 の表層に打ける堆積物は比較的粒径が大 きいことから, 通常の堆積過程や海洋投入土砂の投入直 後における直接的な堆積とは異なると推察される.

具体的にCore 1 に関しては，表層 $20 \mathrm{~cm}$ は粒径 0.15 $0.2 \mathrm{~mm}$ 程度の砂で, それ以深においては粒径 $0.13 \mathrm{~mm}$ 程 度の非常に細かい粒径で構成されていた。つまり, 表層 から $12 \mathrm{~cm}$ 付近と $30 \mathrm{~cm}$ 付近に海洋投入土砂由来の堆積物 の影響が見られるものの, 両者は一度に堆積が進行した ものではなく, 表層から $30 \mathrm{~cm}$ 付近の層は土砂の海洋投 入直後に堆積した層であり, 表層から $12 \mathrm{~cm}$ 付近の堆積 層はその後, 他の地点において侵食された土砂の再堆積 によって形成されたものであると考えられる.すなわち， この再堆積が表層において, 新しい貝殼と古い貝殼が混 在した状態を形成したと推察される.さらに水深が深い ため堆積速度が遅いことから, Core2やCore3のように表 層において, その後の通常の堆積過程による堆積層を明 確に分別できなかったと考えられる.

Core4に関しては, 表層 $45 \mathrm{~cm}$ は粒径 $1 \mathrm{~mm}$ 程度の粗粒分 で構成され, それ以深においては粒径 $0.14 \mathrm{~mm}$ 程度の細 粒分で構成されていた。すなわち, 表層から $45 \mathrm{~cm}$ 付近 の上層と下層は同じ海洋投入土砂由来の堆積物であって も，堆積過程が異なると考えられる. Core4の採取地点 は水深が比較的浅いため, 波高の大きい時化の際には土 砂は比較的容易に移動することから, 海底面の急激な侵 食や堆積が生じやすい. 実際に, 図-3に示す海底地形に
おいても, Core4の採取地点は等深線が凹んでおり, 沿 岸方向の地盤高と比較して地盤が低く，このような地形 は高波浪等により侵食が生じたことで形成されたもので はないかと考元られる。すなわち, Core4においては 1965年以降に土砂の海洋投入に伴う堆積が生じた後, 過 去の低気圧の通過等によって現在の表層から $45 \mathrm{~cm}$ の面 まで侵食を受け, 侵食により周囲と比較して水深が深く なったことから再び堆積が生じやすい状態となり, 表層 $45 \mathrm{~cm}$ の粗粒分が急激に堆積したと推察される.

\section{5. おわりに}

本研究では, 放射性炭素年代測定法により海底土砂中 に含まれる貝殼の年代を測定することで, 過去に海洋投 入された土砂の堆積状況を評価し, 海底土砂の移動・堆 積履歴を推定した. 本手法は各水深帯での土砂のお抢よ その移動・堆積履歴を推定できることが示され, その結 果, 海洋投入土砂は水深 $19 \mathrm{~m}$ 帯にも十分に到達し, 堆積 を生じさせたことが示された．また，堆積した海洋投入 土砂は比較的水深が深い領域に打いては，あまり移動し ていない一方で, 比較的水深の浅い領域に打ける侵食に より, 一部の海洋投入土砂は移動し, 他の地点において 再堆積を生じさせていることが示された。

謝辞：本研究の一部は, JSPS 科研費若手研究（B）「年代 トレーサーを用いた海洋投入土砂の長期移動・堆積特性 と地形変化への影響の推定」(課題番号：25820235) の 助成による成果である。また, 本研究の実施にあたり, 現地調查, 粒度分析において（独）港湾空港技術研究所, 柳嶋慎一氏の多大な協力を受けるとともに, 同氏から 様々な助言を頂いた。ここに記し感謝の意を表する。

\section{参 考 文 献}

井内美郎・斎藤文紀 (1993)：海跡湖の地史-3 霞ヶ浦, URBAN KUBOTA, No.32, pp.56-63.

熊谷隆宏・中嶋さやか・琴浦毅（2009）：貝殼片混合砂の掃流 移動特性に関する実験的研究，土木学会論文集 B2（海岸 工学), Vol.65, No.1, pp.531-535.

小松原純子・木村克己（2011）：埼玉県川越市下老袋地区から 採取した荒川低地の沖積層ボーリングコア (GS-KSO-1) の堆積相と堆積環境, 堆積学研究, Vol.70, No.2, pp.93103.

佐藤昭二 ・田中則男 - 佐々木克博 (1974）：鹿島港建設に伴う 海底地形変化について, 港研報告, Vol.13, No.4, 78p.

武若 聡・笹倉慎也・ Elsayed GALAL - 柳嶋慎一 (2009)： 2006年秋期低気圧による鹿島灘の侵食, 土木学会論文集 B, Vol.65, No.4, pp.277-284.

Shishikura, M., T. Echigo, H. Kaneda (2007): Marine reservoir correction for the Pacific coast of central Japan using ${ }^{14} \mathrm{C}$ ages of marine mollusks uplifted during historical earthquakes, Quaternary Research, Vol.67, No.2, pp.286-291.

Stuiver, M. and Polach, H.A. (1977): Discussion : Reporting of ${ }^{14} \mathrm{C}$ data, Radiocarbon, Vol.19, No.3, pp.355-363. 